Оригинални научни рад

Zoltán Nagy, Ph.D., Associate Professor

University of Miskolc

Faculty of Law

\title{
THE ROLE OF ENVIRONMENTAL TAXATION IN ENVIRONMENTAL POLICY ${ }^{1}$
}

Abstract: In recent years the issue of sustainable development and environmental protection have become a central issue, because of the increasing pollution. Environmental policy applies different types of instruments in order to realize the goals of environmental protection and sustainable development. Although the scale of these instruments are wide, but as the experiences show the economic instruments are the most effective ones considering all of the adverse consequences. Environmental taxes have got more and more significance between the economic instruments. Their significance can be showed by their revenues. In the European Union's regulation the supranational harmonisation of these instruments is inevitable, which is well represented by the regulation of energy taxation. Lots of barriers and counterarguments can be brought up against environmental taxes but a better instrument in the field of environmental regulation has not been invented yet.

Key words: environmental taxes, environmental protection

\section{Introductory thoughts}

The OECD countries and within them also the EU are dealing with some problems, which have arisen from this issue. ${ }^{2}$

These are:

- levying taxes and fees,

- tax rates,

- tax burden,

1 „This research was (partially) carried out in the framework of the Center of Excellence of Sustainable Resource Management at the University of Miskolc."

${ }^{2}$ OECD: Implementation Strategies for Environmental Taxes. In: Kiss Károly: Zöld gazdaságpolitika, BKÁE, Budapest, 2005. 100-115. pp. 
- administrative issues,

- tax adjustment along the border.

When taxes and fees are being levied, the damages - which have been caused directly or indirectly by them - are needed to be considered during the regulation. The application of taxes is efficient, if the contamination is significant and immovable, while the application of fees is expedient, if the contamination is insignificant and the consumption of a product is significant and scattered.

Acceptability of the taxes and fees has a basic impact on efficiency. Two important elements increase the acceptability; firstly the connection with the environmental damages and secondly the return of environmental taxes to the polluter. If the tax's connection with the environmental damages is weak, then it hardly influences the polluters' attitude. Pollution can occur equally in the field of production and consumption, so taxation has to influence also the polluting level of production and consumption. The return of environmental taxes to the polluter increases the accessibility of taxes.

The OECD Report points out that the substitution effect has to be excluded, i.e. the taxpayer moves pollution from one environmental element to another, and also induces substitute activities. It is also important to mention that the taxation have to be calculable and stable in the long term: this plays a particularly important role in investments' decision.

The optimal rate of tax basically impacts the efficiency of taxation. The environmental aim has to be kept in mind when defining the rate of tax, because an optimal rate, which can be modified continuously, helps to reach the optimal level of environmental protection. (If the tax rate is defined at a low level, it will not lead taxpayers to reduce pollution, application of high rates influences taxpayer to use illegal solutions.) It is expedient to define the rate differentially, because a low rate is proper to reach environmental aims in long terms, but the higher rates are efficient for reaching short term goals. The differentiation according to the pollutant content is also very important.

As far as possible the amount of products has to be the base of eco taxation and not its value, because the worsening of the quality is an optional loophole from taxation.

Of course the tax rate has to be reviewed periodically thanks to the inflation, changes in relative prices or the realization of environmental aims.

The problem with tax burden is that the taxpayer passes on the tax burden, i.e. the taxpayer and the person, who actually pays the tax are different. According to this the consumer, the owners of capital, the worker, the owner of natural resources can pay the taxes and fees. Tax payers try to passes on the tax burden according to their position in market, which can induce social or economic problems. So the social or economic impacts have to be considered when a new tax or fee is introduced. 
The analysis of administrative issues is important because it is important to analyse whether the tax collected is proportional to the cost and administration of its collection. Environmental taxes and fees mean relatively low revenue in a tax regime. (Other taxes have got more income for the budget e.g. VAT, personal income tax...etc.) Using regular tax authorities for collecting tax revenues from eco taxes and fees is a cost-effective solution. The integration of these taxes and fees into the existing tax regime entails cost reduction.

When discussing the issue of tax adjustment along the border, the international aspects have to be considered too. Wrongly chosen taxation can affect international competitiveness and the efficiency of economic instruments. From the aspect the problem of taxes on production and on consumption is different. Taxes on production affect only the national production, but nevertheless if taxes on the substitute product in the neighbouring countries are lower the issue of international competitiveness also arisen. In the case of the taxes on consumption not only the national, but the imported products are taxed. If the product can be substituted then the demand for the replacement product can increase.

\section{Advantages and disadvantages of the application of environmental taxes}

From the aspect of environmental policy the analysis of the advantages and disadvantages of environmental taxes are important, because through the analysis it can be defined, which type of tax can give the most optimum result in reaching the aims of environmental policy. The literature highlights the advantages and disadvantages: ${ }^{3}$

The advantages of environmental taxes:

- Minimising cost factors. The costs of reducing pollution differ according the polluters and technologies, therefore the taxes are suitable for reaching the optimal level of pollution with the lowest costs. On the other hand, the costs of the regulatory authorities do not rise, like in the field of direct regulation.

- Static incitement. The effective management of the given technology in order to the performance of emission. In many situations the technology itself cannot reach the optimum level of pollution, but the punctual and professional management of technology is very important. The taxes incite the polluter to use the technology effectively.

${ }^{3}$ Don Fullerton - Andrew Leicester - Stephen Smith: Environmental taxes. NBER Working Paper No. 14/97. www.nber.org/papers/w14/97. (date of download: 2012. 07. 01.) 6-20.pp, Ђорђе Попов, Политике заштите животне средине-економско-правни аспекти, Зборник радова Правног факултета у новом Саду 3/2011, 23-41.pp.

The advantages and disadvantages are analysed based on these authors' work. 
- Dynamic incitement. It basically means the incitement for using new technologies and reducing pollution of the environment. The regulation with prescribing the level of environmental pollution does not incite the polluter to reduce the pollution below the prescribed level. The polluters often aware of performing pollution below the expected level, so the level will be prescribed in lower levels. But taxation means a continuous incitement for reducing continuously the pollution, namely below the prescribed level. Tax refund means a source for developing new technologies, which can generate more and more cost effectiveness.

- General regulation. Taxes are unified for all of the polluters, so the regulation cannot take into account the different types of polluters. For creating an effective regulation it is inevitable to negotiate with the polluters about the rates and technological expectations of the environmental regulators. But this method can worsen the effectiveness, because the polluters can soften the regulators and can require specific exemptions. In the case of taxes this danger does not exist, so the environmental effectiveness does not reduce through the normativity of taxes.

- Cost-limiting properties. The rates of the taxes restrict from above the cost of reduction, with this protecting the polluters from the risk of cost reduction. It can occur that the costs of reducing the level of pollution are significantly higher than the resulted environmental benefits. But in the case of taxes it is eliminated, because if the cost of reducing pollution is higher than the taxes rates the polluter rather paying the higher tax rates than paying the higher costs to reduce pollution.

But environmental taxes also have significant disadvantages, which are also important to be analysed for applying or eliminating them effectively. It has to be stated that the application of environmental taxes can be inefficient.

The disadvantages of the environmental taxes are:

- Uncertain environmental impact. The environmental taxes have got an incentive effect, but they do no guarantee the level of contamination, as against the direct regulation. It was highlighted in the part about of the cost-limitation effect, that there is a type of cost, where the affected parties undertake the pollution, so in a case, where the punctual performance of the environmental aim and the compliance of the pollution's level are important, may not be sure, that the taxes have got the sufficient effectiveness.

- Decision-making structure. The effective application of the taxes is influenced by the decision-making structure, the restructuring costs. This problem is not arisen for small enterprises, but for the bigger ones the harmonisation of paying environmental taxes, choosing the proper technology to reduce the pollution and cost analysis means a big problem. The transformation of the deci- 
sion-making structure and the enterprises means significant costs, therefore if the environmental tax rates are low, this does not induce reorganization processes for the enterprises. It follows therefrom that the enterprises rather pay environmental taxes than reduce pollution.

- Lack of experience. The lack of experience means a significant barrier in the field of the application of environmental taxes. It is evident that there are fields of the application, where the lack of experience exists, but if the application of direct instruments is disadvantaged, the environmental taxes are applied. It can be generally stated, that the OECD countries and the EU have got enough experience about the application of environmental taxes.

- Administrative and enforcement costs. The application of direct instruments and environmental taxes also require regulatory, administrative and enforcement mechanisms. In case of taxes on emission the punctual definition of emission rates, the control of production data also makes it difficult to define and collect the tax. However the environmentally harmful effect is less documented (e.g. logging, water pollution) so illegal activities can be realized. It is highly reasonable to maintain the expensive enforcement mechanism for controlling these activities.

- Differences between emission sources. The changes of the damages caused by pollution depend on the emission sources, but generally a unified emission tax is applied for different emission sources. The unified emission tax is not as efficient as the source based tax assessment. The same tax regulation does not have to be applied for all of the emission sources; however with differing between the sources the polluter's lobbying activity can impact environmental policy. So in many cases the less efficient unified taxes are applied.

- Activities to avoid pollution. Environmental taxes may have environmental damaging impacts, which can be more serious than not having any regulation at all. Taxes on waste materials can incite reducing waste, but it can also induce illegal placement and waste incineration. In this case the social cost of subsequent disposal and environmental degradation is bigger than the cost and impact of pollution.

- Political considerations. Environmental taxes are not always accepted politically. The environmental impacts, such as pollution control is politically accepted, but the polluters reject the taxes in many cases and prefer to the application of other instruments on them, which way polluters can influence political positions.

- The effects of distribution. Generally environmental taxes are applied to transportation, the carbon content of fuels or energy. The majority of the expenditure of households with low income consists of the costs of energy and tran- 
sportation, so with the increasing of environmental taxes the prices will increase and the households' income will decrease. The change of environmental tax rates affects less the households with higher income, whom are willing to spend more on cleaner environmental.

- Attitude. The polluters' attitude and perception can strengthen or weaken the impact of environmental taxes. With levying environmental taxes, the taxpayers' environmentally responsible behaviour can be incited, but also may have other impacts, such as when the tax payer may think that with paying the tax he/she legitimate polluting activities.

\section{European experiences of environmental taxation}

The different types of environmental taxes play a more and more important role in the European Union, and also the revenue from these taxes has been increased. They firstly appeared in 1990s, and their role in the environmental policy has been increased.

The literature also shows their importance in the fields of energy, fuels, transportation, water, waste management and other ecological fields. ${ }^{4}$

The Renaissance of energy and fuels taxation was induced by the Rio Conference in 1992. The Conference stated that the cause of global warming is the greenhouse gas emission from industrial production. The state parties undertook the reduction of greenhouse gases. The European Union applies taxes on energy and carbon dioxide to meet with the Rio's Conference obligations. The EU considered energy taxation the best economic instrument that is why the European Union has developed such a coordinated energy taxation regime.

Taxation on fuels has got a long-standing tradition in Europe. Fuel taxation has been in practice in Dania since 1917, while in Norway since 1931.

Taxes on fuels greatly differ in the Member States. The highest tax exists in Great Britain. ${ }^{5}$ The other difference between the Member States is showed in the tax rates, because the rates depend on the various types of products. Tax rates are different for diesel and gasoline fuels. Most of the states maintain relatively low tax rates for diesel due to transportation and road traffic. The following example clearly shows the impact of the tax: the ultra-low sulphur diesel is sold in the highest amounts in Great Britain, thanks to its lowest tax rates.

${ }^{4}$ Agnieszka Laskowska - Frank Scrimgeour: Environmental taxation: The European experience. (date of download: 2012. 07. 10.) wms-soros.mngt.waikato.ac.nz/NR/EuropeET.doc 112. p. Basically these experiences based on this literature.

${ }^{5}$ Andrew Field: UK Environmental Tax Policy and Climate Change Levy. HM Treasury, UK. Brussels, 2002. 15. pp. 
Table 1. A comparison of taxes levied on motor fuels (shown in terms of the highest tax rates by setting the tax rate applied in the UK equals 100).

(Laskowska-Scrimgeur) $^{6}$

\begin{tabular}{|l|c|c|c|}
\hline & Petrol leaded & Petrol unleaded & Diesel \\
\hline Austria & $55 \%$ & $52 \%$ & $37 \%$ \\
\hline Belgium & $63 \%$ & $63 \%$ & $38 \%$ \\
\hline Denmark & $69 \%$ & $66 \%$ & $45 \%$ \\
\hline Finland & $73 \%$ & $72 \%$ & $42 \%$ \\
\hline France & $72 \%$ & $75 \%$ & $51 \%$ \\
\hline Germany & $70 \%$ & $72 \%$ & $49 \%$ \\
\hline Greece & $39 \%$ & $42 \%$ & $33 \%$ \\
\hline Ireland & $52 \%$ & $48 \%$ & $42 \%$ \\
\hline Italy & $66 \%$ & $69 \%$ & $53 \%$ \\
\hline Luxemourg & $48 \%$ & $48 \%$ & $33 \%$ \\
\hline Netherlands & $75 \%$ & $76 \%$ & $45 \%$ \\
\hline Norway & $83 \%$ & $83 \%$ & $67 \%$ \\
\hline Portugal & $55 \%$ & $45 \%$ & $32 \%$ \\
\hline Spain & $46 \%$ & $48 \%$ & $352 \%$ \\
\hline Sweden & $68 \%$ & $66 \%$ & $48 \%$ \\
\hline Switzerland & $57 \%$ & $58 \%$ & $61 \%$ \\
\hline UK & $\mathbf{1 0 0 \%}$ & $\mathbf{1 0 0} \%$ & $\mathbf{1 0 0 \%}$ \\
\hline
\end{tabular}

The table clearly shows that the lowest tax rates are applied in the Southern European countries (Greece, Spain and Portugal). It is especially true for tax rates of diesel, which is significantly lower in some countries than in the highest rates in the UK.

Special regulation methods exist in the Member States for fuel taxation. Tax rates of energy products depend on the value of inflation in the Netherlands. Italy introduced carbon dioxide taxation for motor fuels in 1999, but simultaneously due to the reduction of energy taxation the consumption of petrol has increased since then. Spain reduced taxes on transport and the value of subsidies on renewable energy sources in order to curb inflation.

Tax rates for fuel taxes are also different in the Central-Eastern European countries. The Scandinavian countries are the leaders of carbon dioxide and sulphur taxation, besides Germany, Italy, French and England. Emission has been decreased since the introduction of the Danish carbon dioxide tax in 1995. Sulphur taxation also has got its positive features in Denmark, thanks to its in-

\footnotetext{
${ }^{6}$ Laskowska - Scrimgeur: op.cit. 3. pp.
} 
troduction in 1996. The introduction has got many consequences: the sulphur content of petroleum products has decreased, technology and sulphur treatment plants have been developing. The tax was introduced by Finland in 1990 and by Sweden in 1991; thanks to this the emission values have decreased on the long run in both states.

In the field of fuel taxation the most controversial issue is aviation fuel tax's environmental tax exemption. Direct taxes exist linked to air transport (noise level, landing fees... etc.), but in fact direct taxes on fuel has not been introduced. (Norway introduced firstly direct tax on aviation fuels, but the international airlines were exempted from the tax due to international pressure.)

Emission taxes and fees were introduced since the 1970s in the Central-Eastern European countries. Firstly these had not got any economic function, because the market economy has not existed yet. In the region different types of air pollution taxes exist, but their success and applicability is different, although their revenue raising function is bigger than their pollution reducing function. Their other important feature is that a low amount of sources are available for realising environmental aims, because the states' budget is in a bad situation, so thanks to this feature special environmental funds exist in some countries (Czech Republic, Poland and Slovakia) for collecting tax revenues. Their third feature is that high-polluting companies have become the primary taxable persons of taxes.

Air pollution and transport taxes have got a significant role in order to improve the air quality in Europe, however sometimes the defined limits are crossed. Transport is the main source of air pollution in the European countries, mostly in large cities, overtaking industrial pollution. (Within transportation road traffic's pollution emission is the most significant.) The European Union's regulation has made big steps in order to reduce the vehicles' emission (catalyser, unleaded petrol), however the improvement was offset by the continuous growing number of vehicles.

Different types of regulation are applied in the European countries:

- fees and taxes related to the purchase and registration of vehicles (registration tax),

- fees and taxes related to the possession and ownership of vehicles (vehicle tax),

- fees and taxes directly or indirectly related to the use of vehicles.

These fees and taxes are complex, i.e. a state's regulation is complex too, but the differences between the Member States are significant. Their common feature is that the biggest part of environmental tax revenues is come from these taxes.

Some states have got registration tax, which charges the purchase of vehicles. Its environmental feature is showed in its rates because lowest rate are defined for vehicles which have low pollutant emission. 
Vehicle tax means a widespread tendency in Europe. The tax base is defined by the weight of the vehicle, the engine capacity and the cylinder capacity. The vehicles' fuel consumption and pollution measures influence tax rates, which are positive from the aspect of environmental protection, because it can influence the development of environmentally friendly technologies and vehicle types. Tax rules prefer electric vehicles to other types, but their number in Europe is negligible. (It has to be stated that the hybrid-electric and the combination of diesel and petrol vehicles has been spreading, so tax law has to prefer this.) ${ }^{7}$

Road user charges have been spreading in Europe, which is linked to the use of the vehicles. The road charge can occur as tolls, congestion charges or other charges on trucks. The congestion charge was firstly introduced in Norway, which was applied to large cities to reduce the environmental load, which was caused by mostly transportation. London can serve as a model for congestion charge too, where the downtown's environmental load was reduced due to this instrument. The most common type of road user charges is toll, which is used in all of the European countries.

Fees and taxes linked to water are hard to be compared, because the most of the fees are introduced at a regional or municipal level. The fee on waterconsumption is regulated in different ways, because the measurement of water consumption is not a widely used method, i.e. rather special tariffs and flat rates are in use. The tax base can be the value of the property (England) or the location of the house (Norway). Special tariffs are in use (block tariffs) in some big cities (Zürich, Barcelona), because the cost of water supply and wastewater service means the part of local taxes. The VAT of water supply and wastewater treatment is different, because normal taxes are used in some countries (Denmark, Finland), and in others these services are below the reduced rate of VAT (Belgium, French, Germany). The Dutch tax on the use (depending on the value of consumption) of groundwater was introduced in 1995, and a new tax on water transportation was introduced in 2000. Denmark introduced the water tax for households in 1994.

Fees and taxes on waste water are widespread in Europe, and in some countries a similar regulation is in force.

Two types of waste taxation exist; firstly charges on waste collection and disposal, and secondly the waste tax. The regulation of the charges is different not only between the countries, but also within the states. For instance in Italy the tax base was the floor-space for households until 1998, and ever since 1999 the charge consists of two elements: a fix and a variable charge. The fix part co-

${ }^{7}$ Цвјетана Цвјетковић, Опорезивање путничких аутомобила као инструмент заштите животне средине, Зборник радова Правног факултета у Новом Саду 3/2012, 375-376. pp. 
vers the cost of disposal, while the variable charge changes with the proportion to the amount of waste.

Most of the Member States has introduced a waste tax but still differences can be found in tax rates and also in the whole regulation. Generally tax rates depend on the type of the waste, and the method of disposal. We can find differences between the Member States in the field of the methods of disposal. The waste, which is transported into a waste incinerator is tax exempted in the Netherlands. The Danish tax policy follows the preferences of waste management. It favours recycling with a zero tax rate and waste incineration with energy recovery. Waste burial is the least preferred tax law solution, because its tax rates are the highest.

The environmental policy is responding to the changes in the field of environmental pollution. In many cases new taxes and fees are introduced to meet with the new challenges. These fields are the agriculture, pesticides, taxing tourism, the latter is linked to the field of other ecological taxation.

In the field of agriculture fertilizers and pesticides have got more and more impacts on water quality in Europe. The Scandinavian countries, the Netherlands and Belgium created a sector specific environmental taxation, which is not typical in other states. Denmark was the first Member State, which introduced tax on pesticides in 1998, and also increased the tax rates of agricultural use of materials. The tax on pesticides is structurally complex in Norway. Pesticides were categorized in different groups based on their risks on health and environmental, and accordingly this grouping defines their tax rates.

The Spanish tax on tourism is a special environmental tax, which affects the tourism of the Balearic Islands and its aim is to balance the environmental consequences of mass tourism. (Every tourist is taxable, regardless of the type of accommodation.)

The environmental taxes show a special distribution in terms of the States' regulation and the number of the tax payers. The literature clearly shows the role of the taxes in the tax regime of the Member States. ${ }^{8}$

Energy tax is the most significant tax in the European Union (energy taxation basically mean carbon, gas oil, natural gas, electricity, transport related energy and carbon dioxide taxes.) In the EU-27 the energy taxes gives the $72 \%$ of environmental taxes, at national level the amount is almost the same, but it has to be stated that the revenues of energy taxes do not go below $50 \%$.

Transport taxes give the $24 \%$ of environmental taxes. These taxes basically mean taxes for the owners and users of vehicles. This type of environmental tax

\footnotetext{
${ }^{8}$ Marina Anda Georgescu - Velina Pendolovska - Julio Cesar Cabeca: Distribution of environmental taxes in Europe by tax payers in 2007. Eurostat 67/210. http://ec.europa/eurostat (date of download: 2012. 07. 10.) 2-7. pp. The authors defined four types of environmental taxes i.e. energy, transport, pollution and resource taxes.
} 
is significant in some European countries (such as in Malta, Cyprus, Ireland, Greece and Norway), because it gives more than the $40 \%$ of taxes.

The resource and pollution taxes (taxes on extraction of raw materials, water and air pollution taxes, and waste management taxes) give the $4 \%$ total environmental taxes. Only a few states exceeded this rate. (The rate was more than $10 \%$ of these taxes in Estonia, Slovakia, the Netherlands, Denmark and Norway.)

Table 2. Environmental Taxes in EU-27 (2007)

(Eurostat-Georgescu-Pendolovska-Cobeca, 2007) ${ }^{9}$

\begin{tabular}{|l|c|c|c|c|}
\hline $\begin{array}{l}\text { Environmental } \\
\text { Taxes }\end{array}$ & million euro & $\begin{array}{c}\text { \% of total } \\
\text { environmental } \\
\text { taxes }\end{array}$ & \% of GDP & $\begin{array}{c}\text { \% of total } \\
\text { revenues from } \\
\text { TSC }\end{array}$ \\
\hline Energy taxes & 219244.14 & 72 & 1.77 & 4.46 \\
\hline $\begin{array}{l}\text { Transport } \\
\text { taxes }\end{array}$ & 71884.87 & 24 & 0.58 & 1.46 \\
\hline $\begin{array}{l}\text { POllution/Re- } \\
\text { source taxes }\end{array}$ & 13139.33 & 4 & 0.11 & 0.27 \\
\hline $\begin{array}{l}\text { Total environ- } \\
\text { mental taxes }\end{array}$ & 304268.34 & 100 & 2.46 & 6.19 \\
\hline
\end{tabular}

The literature also highlights that environmental taxes are mostly consisted of energy and transport taxes, because these tax subjects are responsible largely for the emission of greenhouse gases. It is needed to be emphasized, that 5 Member States are responsible for the $60 \%$ of total greenhouse gas emission in the EU, namely Germany, England, Italy, France and Spain.

This amount of environmental pollution is appeared in taxation too, because these 5 Member States represent $65 \%$ of total tax revenues. (In 2007 tax revenues were: in Germany 54 billion euros, in England 50 billion euros and in French 41 billion euros.) Denmark, Sweden and Norway are contrary examples, because the share of taxes is more than the amount of greenhouse gas emission. Although in many countries this rate is the opposite, because the share of energy and transport taxes is less than the amount of greenhouse gas emission. (These countries are Poland, Slovakia, the Czech Republic, and Romania.)

Another important question is who the taxpayers are. The literature analyses the taxpayers in three groups, i.e. households, enterprises and public sector. The $20-60 \%$ of energy taxes is paid by the households; the $25-75 \%$ is paid by the enterprises and the public sector pays only a little amount of the tax burden.

\footnotetext{
${ }^{9}$ Georgescu - Pendolovska - Cabeca (2007.): op.cit. 2.pp.
} 
In the case of transport taxes the situation is also the same, because the households pay the $55-75 \%$ of taxes in the Member States. (Estonia and Latvia are exceptions, because in these countries the $25-30 \%$ of transport taxes is paid by the households; and Spain where this ratio is 30\%.) In most countries the enterprises pay the $15-41 \%$ of transport taxes. (Lithuania, Estonia and Latvia are exemptions, where this ratio is over $68 \%$.) The public sectors' contribution to the tax burden is negligible, because in many cases public transport is exempted from the tax. In Member States households and enterprises pay the $80 \%$ of total pollution and resource taxes' burden, thus public sectors' contribution is negligible.

The literatures' data clearly shows that the UK is one of the most significant tax revenue-producing countries in the EU, where all types of environmental taxes have been introduced: ${ }^{10}$

- waste tax,

- climate change levy,

- raw materials' tax,

- excise duty on fuel,

- vehicle tax,

- London's congestion charge.

Waste tax was introduced in 1996 on waste delivered to landfill. ${ }^{11}$ Tax rates favoured inactive waste (construction waste) with levying lower tax rates on this type of waste. Tax rates were continuously increased in order to decrease the amount of waste (by 2009 the tax rates of general waste was increased from 24 pounds/ton to 40 pounds/ton; in the case of inactive waste from 2 pounds/ton to 2,5 pounds/ton.) The original tax rate was determined by the estimation of the externalities of landfills; further increases were determined in order to influence the activities concerned to waste collection and treatment. The regulation leaded to a $60 \%$ reduction of inactive waste, and changes were experienced in the amount of waste transported into landfills. In $199684 \%$ of urban waste was in landfills and only $7 \%$ was recycled and by 2005 this ratio was changed to $67 \%$ and $24 \%$.

Climate change levy (CCL) is basically a tax on the amount of energy used by enterprises, which was introduced in 2001 by the government as a part of the climate change programme. The scale of tax exemptions is wide. The energy consumption of households and the transport sector is exempted from the tax.

${ }^{10}$ Fullerton - Leicester - Smith (2007.): op.cit. 4-5. pp. The English environmental taxation regime will be presented based on these authors.

${ }^{11}$ Csák Csilla: A hulladék fogalmának értelmezése az uniós ítélkezési gyakorlat alapján. Pulicationes Universitatis Miskolciensis, Sectio Juridica et Politica, Tomus XXXIX/2. Miskolc University Press, Miskolc, 2011. 
Other tax exemptions are: fuels used to generate electricity, fuels for non-energy purposes and energy from new renewable sources (solar or wind energy). Primarily tax revenues are used to finance energy-efficient technologies. This type of tax reduced with 16,5 million tonnes the pollutant emission that is why this tax is efficient.

The raw materials' tax was introduced in 2002 on the commercial use of sand, gravel and stone. Its aim is to reflect the environmental costs of quarrying. The head of the production pays the tax. There are many tax exemptions such as: coal and ore mining, raw materials used in cement and whitewash production, industrial waste, road constructions and maritime dredging. A part of the revenues is collected in a special fund, of which liquid assets are used for financing environmental aims. The tax's environmental impact can't be directly measured, but an $8 \%$ reduction of raw material flow can be seen because of the tax, which assumes a more economical use under the same construction product.

Important steps were taken in the field of excise duty on fuel in order to favour those fuels, which emit less pollutant than others. Firstly a differentiation in tax levels was done in 1987, when unleaded petrol's tax rate was favoured. The aim was to incite the consumption of unleaded petrol and to compensate its bigger price. (Unleaded petrol was removed from England in 2000.) Steps were made to remove the differences between the tax rates of petrol and diesel. The report of the English Air Workgroup showed that the number of diesel vehicles and their pollutant emission are increasing, which significantly affect the cities' air pollution. The legislator eliminated the difference between these tax rates and further fuel oil's tax rate has become higher than the gasoline's. (The regulation defines lower tax rates for fuels, which have lower sulphur content. The taxation of biofuels, gas and bioethanol are favourable.

In 1999 a basic change in the unified taxation of vehicles were made, when the tax regulations favoured cars with small engines. From 2001 vehicles were categorized by their emission rates of carbon dioxide. Two categories were defined. (The first one with a $0-100 \mathrm{~g} / \mathrm{km}$ emission of carbon dioxide means the lowest scale; the second one is the highest scale with an emission more than 225 $\mathrm{g} / \mathrm{km}$ carbon dioxide.)

London's congestion charge was introduced in 2003 on vehicles, which were used in the centre of London. (The charge's rate firstly was 5 pounds.) A wide range of exemptions were defined. People, who live in the zone, have got a $90 \%$ benefit. Taxes, buses, emergency services (ambulances, fire engines), disability certificate holders' cars, gas vehicles, electric vehicles and hybrid vehicles are exempted from the charge. Revenues of the charge are reinvested into public transportation. (This amount was 80 million pounds in 2003.) The environmental impact of the introduction of this charge can be measured, because the traffic was decreased with $25-30 \%$. 
Др Золиман Нађ, ванредни иррофесор

Универзитетеи у Мишколиу

Правни факулиетеи

\section{Улога еколошког опорезивања у политици животне средине}

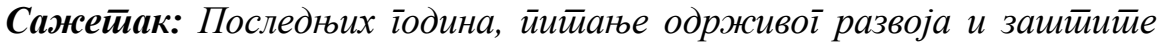
живойне средине йосииало је иентирално йийање, збоі йорасйа заїађивања.

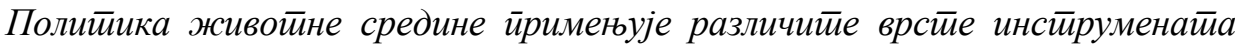
како би се йостииіли ииљеви зашимите живойне средине и одрживої развоја. Иако је лисйа ових инсиируменайа достиа екстиензивна, искустиво је йоказало да су економски инстирумениии најефикаснији у односу на шиеиетне йоследице које моіу да ӣроузрокују. Еколошки йорези добијају све више на значају међу овим економским инсируменииима. Њихова важносии се може доказайи ниховим ирриходима. У йройисима Евройске уније, надначионална хармонизачија ових инсируменайа је неизбежна, за шима је добар иример реїулисање ойорезивања енеріије. Може се навесиии досйа йрейрека и конйра-аріуменайа ирротив еколошких иоореза, али до сада још нису сииворени бољи

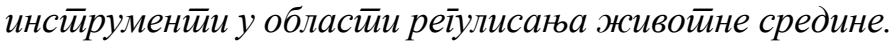

Кључне речи: еколошки йорези, зашйийа живойне средине 